LINGUODIDACTICA XVIII

\author{
Renata Botwina \\ Uniwersytet Warszawski
}

\title{
EDUCATION MEETS ARTS: 'DRAMATIC' EXPERIENCES IN THE FOREIGN LANGUAGE CLASSROOM
}

\author{
SUMMARY \\ Education meets arts: 'dramatic' experiences \\ in the foreign language classroom
}

The article entitled "Education meets arts: 'dramatic' experiences in the foreign language classroom" aims at presenting drama as an effective tool to be used in the foreign language classroom. It describes the beginnings of drama-in-education and presents the most common drama strategies. The author proves that in the modern English language classroom dramabased activities are an invaluable source of meaningful communicative simulations. Firstly, drama motivates shy students to participate in the group activities; secondly, drama-based activities have an endless communicative potential being based on everyday communicative situations; finally, they enlighten the classroom atmosphere and break the ice bringing fun and joy both for the students and the teacher.

Key words: drama-in-education, drama-based activities, drama strategies, communicative approach, motivation, real-life language situations

\section{STRESZCZENIE}

Edukacja spotyka sztukę: 'dramatyczne' doświadczenia w klasie językowej

Artykuł pt. „Edukacja spotyka sztukę: 'dramatyczne' doświadczenia w klasie językowej” ma na celu przedstawienie dramy jako efektywnego narzędzia w nauczaniu języka obcego. Autor opisuje początki dramy w edukacji i przedstawia jej najbardziej popularne strategie. Artykuł dowodzi, iż w nowoczesnej klasie języka angielskiego zajęcia teatralne są nieocenionym 
źródłem komunikatywnych symulacji. Po pierwsze, zajęcia z wykorzystaniem dramy motywują nieśmiałych uczniów do udziału w zajęciach grupowych; po drugie, mają one nieskończony komunikacyjny potencjał; wreszcie, wprowadzają pozytywną atmosferę i przełamują lody w klasie zachęcając do zabawy i radości zarówno studentów jak i nauczycieli.

'Life is like a play: it's not the length, but the excellence of the acting that matters.'

Seneca

Drama, one of the oldest means of arts, is highly appreciated by people of different age and various backgrounds. There are numerous definitions related to the concept of drama due to the fact that scholars approach the concept in different manners. In the most traditional approach, "theatre" is connected to performance, whereas "drama" is linked to the work designed for stage representation ${ }^{1}$. Moreover, theatre is generally believed to be mainly focused on communication among actors and an audience, while drama is mostly related to experience shared by the participants ${ }^{2}$. Usually people associate drama with theatre and plays. Researchers agree that plays constitute a part of drama with the difference that drama can take place everywhere, being not just limited to theatre. It was a long time ago that theatre was successfully introduced into different fields of science. Nowadays drama constitutes an essential tool used in education, psychology, pedagogy, psychiatrics, sociology, etc ${ }^{3}$.

Drama-in-education is known as creative drama - "an improvisational, nonexhibitional, process-centred form of drama in which participants are guided by a leader to imagine, enact and reflect upon human experiences"4. Landy argues that drama-in-education always results in both intuitive and logical thinking involving the two parties - the teacher and the student ${ }^{5}$.

For the first time drama was used in teaching in 1950s. Slade notes that the teaching approach with the use of drama included more free forms of play and improvisation and was a reaction to the inflexible and uncreative approaches used at the time ${ }^{6}$. In its initial form, when used in education, drama required students

\footnotetext{
K. Elam, The Semiotics of Theatre, London 1980, s. 25.

B. Way, Development though drama, London 1987, s. 57.

N. McCaslin, Creative drama in the classroom, New York 1990, s. 10.

4 L. Athiemoolam, The role od drama-in-education in the English second language classroom, http:// www.zsn.uni-oldenburg.de/en/download/Logan_Chennai_Conference.pdf

5 R. J. Landy, Handbook of educational drama and theatre, London 1982, s. 5.

6 P. Slade, Child Drama, London 1954, s. 53.
} 
simply to reproduce the words of others in a formal manner rather than create their own utterances ${ }^{7}$. At the time, the theoretical basis related to drama education was offered only by books on child play and the Humanistic School of Psycho$\log y^{8}$. Gradually, the individual growth of the student and creativity were emphasized as the principal elements of the drama-in-education approach. George Kelly, a leading psychologist of the time, proposed the Personal Construct Theory which challenged to search for the individual psychological power with the minimal help of the therapist ${ }^{9}$.

Drama has been successfully used in FLT for a long time. Francois Gouin, the designer of the Natural Method, deserves a special attention here. In his book "L'Artd'enseigner et d'etudier les languae" Gouin mentions the so-called "Eureka experience" he encountered while observing his son playing. This particular experience encouraged him to develop a brand new approach to foreign language learning and teaching based on the natural connection between action and language production. Fitzgibbon comments on the innovative character of Gouin's approach: "The new element that Gouin brought into teaching of modern languages was intense activity through dramatization of the sentences to be drilled. Language was no longer considered a construct of isolated pieces, something abstract to be anatomised and pieced together again. Language is behaviour - Gouin could say today" ${ }^{10}$. Thus, play, association, mimicry, fun and creative forms of memorization were successfully introduced to FLT and soon became its principle elements.

Schewe has continued Gouin's application of drama in FLT. He suggests using fixed models for a practical application of dramatic principles within English language teaching. This author describes a number of sequences of dramatic lessons on the micro-level offering the ways in which activities can be transformed into instructional models and then successfully integrated into foreign language lessons. According to Schewe, foreign language teaching should be perceived as both a scientific and an artistic discipline. Therefore, foreign language teachers should perceive themselves as scientists and artists, whereas the process of teaching and learning should be seen as a kind of improvisation ${ }^{11}$.

Consequently, Schewe provoked researchers' interest as regards the scale and scope of the impact drama has on education results of the individual learner.

\footnotetext{
Ibidem.

8 E. H. Ericson, Childhood and society, New York 1963, s. 27.

9 Ibidem.

10 E. Fitzgibbon, Language at play. Drama and Theatre in Education as Stimuli in Language Learning, Frankfurt 1993, s. 9.

11 M. E. Schewe, Towards drama as a method in the Foreign Language Classroom, Frankfurt 1993, s. 8.
} 
Since the publication of Schewe's first book, there have been numerous attempts to describe in detail the different dramatic procedures to unite drama and foreign language teaching. Nevertheless, it should be emphasized that despite those attempts there is no comprehensive and systematic typology and terminology for drama-based foreign language instruction.

The humanistic approach towards FLT has brought a need to emphasise the unique nature of every student in the classroom. The teacher is urged to come beyond the "visible" part of the classroom trying to perceive the student as an individual with a unique combination of experiences, talents and aptitude. In this context, drama comes as a perfect tool offering a great range of possibilities: shy students may "hide" their lack of confidence playing somebody else; students are encouraged to work as a group, therefore, the "group" spirit is being developed; finally, foreign language learners are able to build their language skills and develop insights and abilities to understand themselves in the target language.

What is more, O'Neill argues that drama-in-education necessitates the participant to use the language in meaningful and authentic situations in which "the stress is on asking questions and seeking answers to these questions", therefore, "teachers and learners co-create the dramatic "elsewhere", a fictional world, for experiences, insights, interpretations, and understandings to occur" 12 .

In a typical foreign language classroom simulation, drama usuallly starts with setting a a situation which engages and challenges the students to use a foreign language. Next, a series of episodes are improvised, composed and rehearsed for some time for memorization. All the participants are involved in this type of activity and there is no external audience to observe their efforts. The teacher coordinates the procedure and diagnoses the learners' language skills and comprehension. Moreover, the teacher supports learner's communicative exertions, models appropriate language behaviour and linguistic expressions within the specific situations as well as questions students' way of thinking and extends and challenges their responses in the entire process ${ }^{13}$.

The effectiveness of the learning process with the use of drama-in-education increases significantly by the use of multiple ways of learning. Drama combines visual, aural, verbal and kinesthetic layers, which allows for "different points of entry into the work and different ways of becoming involved" 14 . Consequently, by using drama students are able to "fix the learning experience more firmly in their

12 C. O’Neill, Building dramatic worlds in process. Reflections: a booklet on shared ideas on process drama, Ohion 1992, s. 14.

13 Ibidem.

14 H. Nicholson, Drama, literacies and difference, [w:] Where texts and children meet, E. Berne, V. Watson (red.), London 2000, s. 113-122. 
minds"15. This priority corresponds with the NLP philosophy and its VAKOG representational systems - visual, auditory, kinesthetic, olfactory and gustatory sensory based models through which people perceive and absorb information ${ }^{16}$. Therefore, drama, as a complex means of arts, is a perfect tool for students who respond particularly well to visual stimuli and who have a good spatial awareness. They will definitely benefit from drama activities such as creating still images and sculpting. Kinesthetic learners will also enjoy drama for the same reasons - miming and acting out will be particularly interesting for them. Drama conventions may also appeal to those who like auditory style of learning.

To introduce drama into the process of foreign language teaching, the teacher should become acquainted with drama strategies (also known as drama techniques or drama conventions). The knowledge of these strategies can "enhance performance skills including storytelling, character development, mime and movement"17. David Farmer, a freelance drama consultant, storyteller, theatre director and the author of the best-selling 101 Drama games and Activites, mentions the following strategies: role play, teacher in role, mantle of the expert, hot seating, thought tracking, role on the wall, meetings, rumours, and telephone conversations ${ }^{18}$.

Each strategy simulates everyday life situations and provokes students to use the language in a creative way. Let us briefly describe each strategy ${ }^{19}$.

Role play is the basis of all dramatic activity. This requires the students' ability to step into another character's shoes. Role plays come naturally to most learners - young learners are especially keen on them, which can be used to great effect, challenging learners to develop a more sensitive understanding of a variety of viewpoints whilst sharpening their language and movement skills. By adopting a role, language learners can step into the past or future and travel to any location, dealing with different issues. Thus role plays can be easily fixed to meet themes across the curriculum.

According to Farmer, Teacher In Role is one of the most effective tools when it comes to drama-in-education ${ }^{20}$. The teacher takes on the role of some character to take students into an imaginary situation for them to explore, discuss and consolidate language items within a given context. Consequently, the barrier between the teacher and student is broken down since the teacher acts as a participant in the

15 L. Y. S. Chang, Dramatic language learning in the classroom, [w:] Second Language Learning through drama, J. Winston (red.), London - New York 2012, s. 7.

16 R. Botwina, Neurolinguistic programming versus alternative ways of FLT: a step forward, „Linguodidactica" 2010, t. 14, s. 27-39.

17 D. Farmer, Learning through drama, Great Britain 2011, s. 15.

18 Ibidem, s. 16.

19 Ibidem, s. 16-20.

20 Ibidem. 
drama with the students. What is more, the teacher delivers the subject content in a context not typical of a classroom setting, which makes the lesson interesting and special.

Another strategy mentioned by Farmer is Mantle of the expert which involves the creation of a fictional world where students assume the roles of experts in a designated field ${ }^{21}$. Mantle of the Expert is based on the assumption that treating students as responsible experts enhances their engagement and self-confidence. In other words, students learn a foreign language in a meaningful context and deal with the language issues in an interactive and practical way. Thus, language learners acquire skills and knowledge they can apply in their everyday lives. It goes withou saying that this particular strategy encourages creativity, improves teamwork, communication skills, critical thought and decision-making.

Hot Seating is a widely used and very effective drama strategy. The procedure is based on the questions that are asked to someone sitting in the 'hot-seat' area and pretending to act the role decided upon earlier. In this strategy students have an opportunity to ask questions to a character from the piece they are studying or the story they are familiar with ${ }^{22}$.

Thought tracking is a strategy which requires a group making a still image in which students are invited to speak their thoughts or feelings aloud using just a few words. This can be done by tapping each person on the shoulder or holding a cardboard 'thought-bubble' above their head. This strategy is a perfect exercise to be used when having a class at the end of a week or trying to achieve a lively atmosphere in the classroom.

Farmer also mentions Role on the wall, a strategy whic requires the outline of a body being drawn on a large sheet of paper, which is later stuck onto the wall. This can be done by carefully drawing around one of the participants. Language items describing the character are written onto the drawing or stuck on ${ }^{23}$. This drama technique can be carried out as a group activity or by individuals writing about their own character. This is a perfect activity to consolidate the vocabulary dealing with physical appearance, age, gender, location and occupation, as well as topics realted to students' likes/dislikes, friends, hobbies, attitudes, secrets and dreams.

Farmer goes on to describe three more strategies: meeting, rumours, and telephone conversations ${ }^{24}$. A meeting is an imaginary setting for characters in drama

\footnotetext{
21 D. Farmer, Learning through..., s. 16-20.

22 Ibidem.

23 Ibidem.

24 Ibidem.
} 
- a meeting of experts, a family meeting, a town hall meeting, etc. This drama strategy usually requires some prior knowledge of the setting for the students involved since it is asking every participant to take on a role in the meeting. This is a very good exercise to act out the pending meeting and its agenda. The participants are split into various groups so they can discuss their attitudes to the agenda points. When the meeting is over, the various groups comment on the agenda points and the teacher encourages responses from each group.

Rumours and telephone conversations are improvised comments which are passed amongst students to generate and spread ideas about various characters and situation. Students pretend to be talking on the telephone or just passing some news while having an informal conversation. These strategies allow for drama to be successfully introduced in the foreign language classroom. They are both simple and effective tools to encourage students to communicate in the foreign language classroom for they simulate everyday activities.

To sum up, in the modern English language classroom drama-based activities are an invaluable resource of meaningful communicative simulations. Firstly, they motivate shy students to participate in the group activities; secondly, such activities have an endless communicative potential being based on everyday communicative situations; thirdly, association, mimicry and creative forms of memorization allow for a better acquisition of the language material. Finally, drama-based activities enlighten the classroom atmosphere and break the ice bringing fun and joy both for the students and the teacher.

\section{Bibliography}

Athiemoolam L., The role od drama-in-education in the English second language classroom, http:// www.zsn.uni-oldenburg.de/en/download/Logan_Chennai_Conference.pdf

Botwina R., Neurolinguistic programming versus alternative ways of FLT: a step forward, "Linguodidactica" 2010, t. 14.

Chang L. Y. S., Dramatic" language learning in the classroom, [w:] Second Language Learning through drama, J. Winston (red.), London - New York, 2012.

Elam K., The Semiotics of Theatre, London 1980.

Ericson E. H., Childhood and society, New York 1963.

Farmer D., Learning through drama, Great Britain 2011.

Fitzgibbon E., Language at play. Drama and Theatre in Education as Stimuli in Language Learning, Frankfurt 1993.

Landy R. J., Handbook of educational drama and theatre, London 1982.

Way B., Development though drama, London 1987.

McCaslin N., Creative drama in the classroom, New York 1990. 
Nicholson N., Drama, literacies and difference, [w:] Where texts and children meet, E. Berne, V. Watson (red.), London 2000.

O'Neill C., Building dramatic worlds in process. Reflections: a booklet on shared ideas on process drama, Ohio 1992.

Schewe M. E., Towards drama as a method in the Foreign Language Classroom, Frankfurt 1993.

Slade P., Child Drama, London 1954. 